OPEN ACCESS

Edited by: Ilonka Kreitschmann-Andermahr, University of Duisburg-Essen, Germany

Reviewed by: Martin Bidlingmaier, Ludwig Maximilian University of Munich, Germany Roberto Salvatori,

Hopkins University, United States

*Correspondence: Kevin C. J. Yuen kevin.yuen@dignityhealth.org

Specialty section: This article was submitted to Pituitary Endocrinology, a section of the journal Frontiers in Endocrinology

Received: 03 December 2020 Accepted: 11 January 2021

Published: 24 February 2021

Citation:

Yuen KCJ, Miller BS, Boguszewski CL and Hoffman AR (2021) Usefulness and Potential Pitfalls of Long-Acting Growth Hormone Analogs.

Front. Endocrinol. 12:637209. doi: 10.3389/fendo.2021.637209

\section{Usefulness and Potential Pitfalls of Long-Acting Growth Hormone Analogs}

\author{
Kevin C. J. Yuen ${ }^{1 *}$, Bradley S. Miller ${ }^{2}$, Cesar L. Boguszewski ${ }^{3}$ and Andrew R. Hoffman ${ }^{4}$ \\ 1 Barrow Pituitary Center, Barrow Neurological Institute, Departments of Neuroendocrinology and Neurosurgery, University of \\ Arizona College of Medicine and Creighton School of Medicine, Phoenix, AZ, United States, 2 Division of Pediatric \\ Endocrinology, Department of Pediatrics, University of Minnesota, Minneapolis, MN, United States, ${ }^{3}$ SEMPR, Serviço de \\ Endocrinologia e Metabologia, Departamento de Clínica Médica. Hospital de Clínicas da Universidade Federal do Paraná, \\ Curitiba, Brazil, ${ }^{4}$ Department of Medicine, VA Palo Alto Health Care System and Stanford University School of Medicine, \\ Palo Alto, CA, United States
}

Daily recombinant human $\mathrm{GH}(\mathrm{rhGH})$ is currently approved for use in children and adults with $\mathrm{GH}$ deficiency (GHD) in many countries with relatively few side-effects. Nevertheless, daily injections can be painful and distressing for some patients, often resulting in nonadherence and reduction of treatment outcomes. This has prompted the development of numerous long-acting $\mathrm{GH}(\mathrm{LAGH})$ analogs that allow for decreased injection frequency, ranging from weekly, bi-weekly to monthly. These LAGH analogs are attractive as they may theoretically offer increased patient acceptance, tolerability, and therapeutic flexibility. Conversely, there may also be pitfalls to these LAGH analogs, including an unphysiological $\mathrm{GH}$ profile and differing molecular structures that pose potential clinical issues in terms of dose initiation, therapeutic monitoring, incidence and duration of side-effects, and longterm safety. Furthermore, fluctuations of peak and trough serum GH and IGF-I levels and variations in therapeutic efficacy may depend on the technology used to prolong $\mathrm{GH}$ action. Previous studies of some LAGH analogs have demonstrated non-inferiority compared to daily rhGH in terms of increased growth velocity and improved body composition in children and adults with GHD, respectively, with no significant unanticipated adverse events. Currently, two LAGH analogs are marketed in Asia, one recently approved in the United States, another previously approved but not marketed in Europe, and several others proceeding through various stages of clinical development. Nevertheless, several practical questions still remain, including possible differences in dose initiation between naive and switch-over patients, methodology of dose adjustment/s, timing of measuring serum IGF-I levels, safety, durability of efficacy and cost-effectiveness. Long-term surveillance of safety and efficacy of LAGH analogs are needed to answer these important questions.

Keywords: long-acting growth hormone, treatment adherence, growth hormone deficiency, growth hormone replacement, adults, children 


\section{INTRODUCTION}

The long-term safety and efficacy of daily recombinant human growth hormone (rhGH) therapy in children with GH deficiency (GHD) are well-studied (1-3). However, maintaining maximal treatment adherence with daily rhGH injections is challenging, not only for children, but also for caregivers and for adults with GHD because of device limitations, pain at injection sites, inconvenience of daily injections, lack of perceived immediate benefits, insurance barriers, and costs $(4,5)$, leading to frequent dose omissions and treatment cessation (6). Thus, it has been hypothesized that a LAGH analog with a lower injection frequency might help mitigate treatment non-adherence, and thereby potentially improve treatment outcomes.

To this end, many pharmaceutical companies have spent a significant amount of money developing LAGH analogs using a several different yet novel technologies to prolong $\mathrm{GH}$ action that may allow for weekly (7-18), bi-weekly (19-21), or monthly administration $(22,23)$. However, there are theoretical reasons to suspect that LAGH analogs might be inferior to daily rhGH administration. The physiologic secretory pattern of GH occurs in an episodic and pulsatile pattern, with several peaks throughout the day and an increased number in the second half of the night during sleep. Concerns that elevated and nonpulsatile GH exposure may downregulate or desensitize GH receptor signaling were unfounded when a study by Laursen et al. (24) demonstrated that subjects who received continuous subcutaneous infusions of GH over 6 months maintained their serum IGF-I levels within the normal range and did not develop any signs or symptoms of acromegaly. In 1999, the first LAGH analog (Nutropin Depot) was approved and marketed in the United States, but later withdrawn due to manufacturing issues and inferior efficacy reported during post-marketing follow-up (21). The latter problems may be related to increased pain at the injection sites compared to daily rhGH injections. After this experience, the lesson learnt from this experience was that the success of developing future LAGH analogs should not only take into consideration of convenience and ease of injection administration, but also non-inferiority in therapeutic efficacy and a side-effect profile comparable to that of daily rhGH therapy.

\section{TREATMENT OF GHD IN CHILDREN AND ADULTS: WHERE WE WERE AND WHERE WE ARE NOW}

Treatment with rhGH in children with GHD has been wellestablished for over 35 years in inducing linear growth and attaining adult height appropriate for genetic potential (2). In early studies involving children with GHD, these patients were receiving rhGH that were administered intramuscularly three days a week because this dosage regimen was based on several clinical observations of its effects on growth response (25). The concept of administering subcutaneous rhGH injections daily was first proposed in 1983 by Kastrup et al. (26), and this treatment regimen was found to be efficacious in inducing linear growth and less inconvenient to children. By contrast, current recommendations are weight-based or body surface-based dosing at the start of treatment followed by individualized dosing in accordance with clinical response, with higher rhGH doses preferred for those with greater severity of GHD, and subsequent dose adjustments made according to growth response $(1,2)$. Serum IGF-I levels are used to monitor for adherence, efficacy and safety (27); if these levels exceed the upper limit of the age-appropriate reference range, then reductions of the rhGH dose should be considered for safety reasons $(1,2)$. In some cases where treatment response has been inadequate, re-evaluation of other etiologies of short stature and non-adherence are recommended (27).

The first studies assessing the effects of rhGH replacement in adults with GHD was performed in $1989(28,29)$. These studies demonstrated improvements in body composition, exercise capacity, muscle strength, bone remodeling, and dyslipidemia. This prompted a flurry of publications in the literature between 1989 and 1999 in adults with GHD, and the results from many of these studies corroborated with the observations from the two initial pivotal trials in $1989(28,29)$. Further dose-finding clinical studies in various age groups were then performed (30-32) and interestingly, these studies found that adults are inherently more sensitive to the effects of rhGH than children in terms of serum IGF-I generation and rate of side-effects (33), and that males are more responsive to rhGH therapy than females $(34,35)$. These and other data have resulted in the approval for rhGH replacement in children and adults with GHD by the United States Food and Drug Administration (FDA) and European Medicines Agency in 1985 and 1996, respectively, and translated into several published consensus guidelines for the management of children (2) and adults with $\operatorname{GHD}(36,37)$. Subsequent studies in adults with GHD performed since 1999 have further corroborated the positive effects of rhGH therapy on quality of life, exercise capacity and bone mineral density (38). However, whether rhGH replacement can normalize or decrease the mortality rates in these patients remains debatable. Treatment-related side-effects, mainly related to fluid retention and impaired glucose tolerance, are dose-dependent and related to increased GH sensitivity associated with aging, and are often reversible upon dose reductions or treatment cessation. Caution and close monitoring are recommended with an emphasis on lower rhGH dosing at treatment initiation and maintenance to avoid over-treatment, especially in older, obese, and glucoseintolerant patients as they are generally more susceptible to sideeffects. More recent consensus guidelines have emphasized the importance of individualized rhGH dosing in the treatment of adults with GHD, with the primary objective of achieving normalization of age-appropriate serum IGF-I levels (38).

\section{LONG-ACTING GH ANALOGS: USEFULNESS, MECHANISM/S AND CURRENT STATUS}

The main indication for the development of LAGH analogs in children and adults with GHD is to improve patient adherence 
and to ease the burden of chronic daily injections. While many early LAGH analogs were not shown to be effective or practical (39), two LAGH analogs (Eutropin Plus and Jintrolong) are currently being marketed in Asia, one (Somapacitan) was recently approved in the United States, one (Eutropin Plus) was previously approved in Europe but never marketed, and several more close to being considered for regulatory approval in the United States and Europe (Table 1). The methodology for creating LAGH analogs can be classified into two broad groups: formulations that create a subcutaneous depot from which native or modified $\mathrm{GH}$ is slowly released into the circulation, and formulations that permit rapid absorption from the delivery site in the subcutaneous tissue and delayed removal from the circulation. Other new development methods being studied include reversible complexes to stabilize the $\mathrm{GH}$ molecule, fabrication of sustained release preparations that utilize various matrices to bind to the $\mathrm{GH}$ molecule, and structural modifications of the $\mathrm{GH}$ molecule itself.

In 1979, after the publication by Lippe et al. (71) using a depot GH preparation in gelatin solution, the next generation of LAGH analogs to be developed was a native rhGH that was micronized, zinc-stabilized and encapsulated in microspheres (Nutropin Depot). Several other LAGH analogs have since been developed and additional studies performed to assess longitudinal growth velocity in children and changes in body composition in adults as primary endpoints $(16,19,21,22,72)$.

TABLE 1 | Overview of the development history of LAGH analogs.

\begin{tabular}{|c|c|c|c|c|c|}
\hline Company & LAGH analog & $\begin{array}{c}\text { Modification to GH } \\
\text { molecule }\end{array}$ & $\begin{array}{l}\text { Frequency of } \\
\text { administration }\end{array}$ & Current status & Research data \\
\hline \multicolumn{2}{|c|}{ Depot Formulation } & Depot Chemical & & & \\
\hline Genentech & Nutropin Depot ${ }^{\circledR}$ & $\begin{array}{l}\text { Encapulsated in } \\
\text { biocompatible, } \\
\text { biodegradable, } \\
\text { polylactide-coglycolide } \\
\text { polymer microsphere } \\
(22 \mathrm{kDa})(40)\end{array}$ & 14 days & Removed from market (39) & \\
\hline
\end{tabular}

\section{PEGylated Formulations}

Ambrx ARX201

BBT-031

Bolder

BioTechnology

GeneScience

Pharmaceuticals

Co, Ltd

Novo Nordisk

Pfizer

PEGylation prolongs in vivo mean residence time of $\mathrm{GH}$, through slowing absorption and protection from proteolysis

\section{0-kDa PEG added to unnatural 7 days amino acid incorporated into $\mathrm{GH}$ $(52 \mathrm{kDa})$}

\begin{tabular}{|c|c|c|}
\hline & & ineys (44) \\
\hline $\begin{array}{l}\text { Site-specific PEGylated GH } \\
\text { analog (not available) }\end{array}$ & $\begin{array}{l}7 \text { days } \\
\text { (planned) }\end{array}$ & Preclinical studies (45) \\
\hline $\begin{array}{l}\text { 40-kDa PEG attached to GH (62 } \\
\text { kDa) }\end{array}$ & 7 days $(13,16)$ & Marketed in China for CGHD \\
\hline $\begin{array}{l}\text { 43-kDa PEG residue } \\
\text { attached to glutamine } 141 \\
\text { (65 kDa) }\end{array}$ & 7 days & $\begin{array}{l}\text { Unsatisfactory IGF-I profile peak and } \\
\text { duration (46) }\end{array}$ \\
\hline $\begin{array}{l}\text { Branched } 40 \mathrm{kD} \text { PEG on } \\
\text { N-terminus of } \mathrm{GH}\end{array}$ & 7 days & $\begin{array}{l}\text { High rate of lipoatrophy at injection } \\
\text { site (47) }\end{array}$ \\
\hline
\end{tabular}

No longer being developed (39) due to PEGylated-containing vacuoles in the epithelial cells of the choroid plexus in monkeys (44) analog (not available) Jintrolong ${ }^{\circledR}$ NNC126-0083 PHA-794428 (62 kDa)
Phase 3 studies show good IGF-I profile, Phase 4 studies now ongoing No longer being developed as of 2011

No longer being developed as of 2009 
TABLE 1 | Continued

\begin{tabular}{|c|c|c|c|c|c|}
\hline Company & LAGH analog & $\begin{array}{l}\text { Modification to GH } \\
\text { molecule }\end{array}$ & $\begin{array}{l}\text { Frequency of } \\
\text { administration }\end{array}$ & Current status & Research data \\
\hline \multicolumn{2}{|c|}{ Pro-Drug formulation } & \multicolumn{4}{|c|}{ Mechanism of conversion to active drug } \\
\hline Ascendis & $\begin{array}{l}\text { TransCon } \mathrm{GH}^{\circledR} \\
(\mathrm{ACP}-001)\end{array}$ & $\begin{array}{l}\text { Unmodified rhGH transiently } \\
\text { bound to a PEG carrier molecule } \\
\text { via a self-cleaving linker that is } \\
\text { dependent upon } \mathrm{pH} \text { and } \\
\text { temperature }(22 \mathrm{kDa})\end{array}$ & $\begin{array}{l}7 \text { days }(8,12 \\
14,18,48)\end{array}$ & $\begin{array}{l}\text { Phase } 2 \text { studies in CGHD and AGHD } \\
\text { showed comparable GH and IGF-I } \\
\text { profile to daily GH dosing } \\
\text { Phase } 3 \text { studies in CGHD showed } \\
\text { positive growth response (49) }\end{array}$ & $\begin{array}{l}\text { Completed Phase } 3 \text { study in CGHD } \\
\text { and data submitted to FDA and } \\
\text { EMA } \\
\text { Phase } 3 \text { study in AGHD currently } \\
\text { planned }\end{array}$ \\
\hline \multicolumn{2}{|c|}{$\begin{array}{l}\text { Non-covalent albumin binding } \\
\text { GH compound(s) }\end{array}$} & Albumin binding & & & \\
\hline $\begin{array}{l}\text { Novo Nordisk A } \\
\text { S }\end{array}$ & 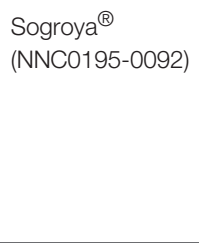 & $\begin{array}{l}\text { Single-point mutation in } \mathrm{GH} \text {, } \\
\text { with albumin binding moiety } \\
\text { attached (non-covalent albumin- } \\
\text { binding properties) }(50,51)(23 \\
\text { kDa) }\end{array}$ & 7 days (52) & $\begin{array}{l}\text { Phase } 2 \text { studies in CGHD showed } \\
\text { comparable IGF-I profile to daily GH } \\
\text { dosing (53) } \\
\text { Phase } 3 \text { studies in AGHD well } \\
\text { tolerated (54-56) } \\
\text { Approved by the FDA in August } 2020 \\
\text { for use in AGHD but not marketed yet }\end{array}$ & $\begin{array}{l}\text { Phase } 3 \text { studies in CGHD, Phase } 2 \\
\text { studies in SGA }\end{array}$ \\
\hline \multicolumn{2}{|c|}{ GH Fusion Proteins } & Protein fused with $\mathrm{GH}$ & & & \\
\hline $\begin{array}{l}\text { Ahngook } \\
\text { Pharmaceutical } \\
\text { Co, Ltd }\end{array}$ & AG-B1512 & $\begin{array}{l}\text { Recombinant GH genetically } \\
\text { fused to a polypeptide linker and } \\
\text { an anti-human serum albumin } \\
\text { Fab antibody } \\
(\sim 72 \mathrm{kDa})\end{array}$ & $\begin{array}{l}14 \text { or } 28 \text { days } \\
(57)\end{array}$ & $\begin{array}{l}\text { Preclinical studies show IGF-I level } \\
\text { elevation sustained for } 20 \text { days }\end{array}$ & Ongoing research \\
\hline Alteogen & ALT-P1 & 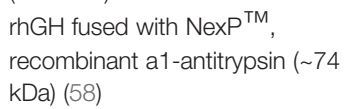 & unknown & Stopped Phase 2 study in CGHD (59) & \\
\hline Asterion & ProFuse $^{\mathrm{TM}} \mathrm{GH}$ & $\begin{array}{l}\text { GH binding protein } \\
(\sim 82 \mathrm{kDa})(60)\end{array}$ & $\begin{array}{l}1 \text { month } \\
\text { (planned) }\end{array}$ & $\begin{array}{l}\text { Preclinical studies to provide } \\
\text { intravascular stores of inactive } \mathrm{GH}\end{array}$ & \\
\hline $\begin{array}{l}\text { Genexine and } \\
\text { Handok }\end{array}$ & $\mathrm{GX}-\mathrm{H} 9$ & $\begin{array}{l}\text { rhGH fused to hybrid non- } \\
\text { cytolytic immunoglobulin Fc } \\
\text { portions of lgD and lgG4 } \\
(100 \mathrm{kDa})(61)\end{array}$ & $7-14$ days $(62)$ & $\begin{array}{l}\text { Phase } 2 \text { studies in AGHD completed } \\
\text { (63) } \\
\text { Phase } 2 \text { studies in CGHD showed } \\
\text { reassuring height changes }\end{array}$ & $\begin{array}{l}\text { Phase } 3 \text { studies in CGHD with } \\
\text { twice-monthly dosing ongoing }\end{array}$ \\
\hline $\begin{array}{l}\text { Hanmi } \\
\text { Pharmaceutical } \\
\text { Co }\end{array}$ & $\begin{array}{l}\text { LAPS rhGH } \\
(\text { HM10560A) }\end{array}$ & $\begin{array}{l}\text { Homodimeric aglycosylated } \\
\text { IgG4 Fc fragment ( } 51 \text { kDa) (64) }\end{array}$ & 7-14 days (64) & $\begin{array}{l}\text { Phase } 2 \text { in AGHD show good } \\
\text { tolerability }\end{array}$ & Phase 3 studies in AGHD (65) \\
\hline $\begin{array}{l}\text { JCR } \\
\text { Pharmaceuticals }\end{array}$ & JR-142 & $\begin{array}{l}\text { Engineered hGH fused at } \\
\text { C-terminus with modified human } \\
\text { serum albumin at } \\
\text { N-terminus ( } 88 \mathrm{kDa})(66)\end{array}$ & 7 days & Preclinical trials & Phase 1 study completed (67) \\
\hline $\begin{array}{l}\text { OPKO Health } \\
\text { and Pfizer }\end{array}$ & $\begin{array}{l}\text { Somatrogon } \\
\text { (MOD-4023) }\end{array}$ & $\begin{array}{l}\text { rhGH fused to three copies of } \\
\text { carboxyl-terminal peptide (CTP) } \\
\text { of hCG } \beta \text {-subunit ( } 47.5 \mathrm{kDa})\end{array}$ & 7 days $(11,15)$ & $\begin{array}{l}\text { Phase } 2 \text { studies in CGHD (68), } \\
\text { Phase } 3 \text { studies in AGHD did not } \\
\text { meet primary endpoint of truncal fat } \\
\text { reduction (17) } \\
\text { Phase } 3 \text { studies in CGHD showed } \\
\text { non-inferior improvement in height } \\
\text { velocity with good tolerability }\end{array}$ & $\begin{array}{l}\text { Phase } 3 \text { study in CGHD completed } \\
\text { (69), and extension studies now } \\
\text { ongoing }\end{array}$ \\
\hline Teva & $\begin{array}{l}\text { Albutropin } \\
\text { (TV-1106) }\end{array}$ & $\begin{array}{l}\text { Human serum albumin } \\
\text { fused to } \mathrm{N} \text {-terminus of } \\
\mathrm{GH}(88 \mathrm{kDa})\end{array}$ & 7 days $(9,10)$ & $\begin{array}{l}\text { Studies in AGHD discontinued for } \\
\text { unknown reason; presumed } \\
\text { unfavorable benefit:risk profile }\end{array}$ & \\
\hline Versartis & $\begin{array}{l}\text { Somavaratan } \\
\text { (VRS-317) }\end{array}$ & $\begin{array}{l}\text { Fusion protein of rhGH } \\
\text { and the pharmacologically inactive } \\
\text { portion of long } \\
\text { chains of natural } \\
\text { hydrophilic amino acids } \\
\text { (XTEN technology) }\end{array}$ & $\begin{array}{l}7,14 \text { or } 28 \\
\text { days }(22)\end{array}$ & $\begin{array}{l}\text { No longer being developed as of } 2017 \\
\text { as the Phase } 3 \text { study did not meet its } \\
\text { primary end-point for non-inferiority } \\
\text { comparison against daily rhGH for height } \\
\text { velocity in CGHD (22) }\end{array}$ & \\
\hline
\end{tabular}

AGHD, adults with GH deficiency; CGHD, children with GH deficiency; EMA, European Medicines Agency; EU; European Union; FDA, Food and Drug Administration; kDa, kilodalton; ISS, idiopathic short stature; PEG, poly(ethylene glycol); rhGH, recombinant human GH; SGS, small for gestational age. Table is modified from Miller BS, et al. (70).

Among them, Eutropin Plus, a depot formulation of rhGH, was approved in South Korea in 1992 and in Europe in 2013, but because it was not marketed in Europe for 3 years, its authorization in Europe lapsed. Jintrolong, a PEGylated GH analog, and Somapacitan, an analog of rhGH containing a fatty acid linker which binds reversibly to serum albumin, have been approved for use in children and adults in China and United States, respectively. In September 2017, Versartis, Inc., the 
manufacturer of Somavaratan (VRS-317), a molecule with extra amino acids added to the head and the tail of $\mathrm{GH}$, reported data from the VELOCITY Phase 3 clinical trial that the drug had failed to meet its primary end-point for non-inferiority when compared against daily rhGH (Genotropin) for height velocity in children with GHD $(9.44 \mathrm{~cm} v s 10.70 \mathrm{~cm}$ for those receiving daily rhGH) (22). Based on these findings, the company subsequently made the decision to suspend its manufacture and all clinical trials, and withdrew its United States Investigational Drug Application and equivalent filings in other countries (73). Other LAGH analogs also met the same fate in being discontinued from manufacture for a multitude of reasons: ARX201 due to the development of PEGylated-containing vacuoles in the epithelial cells of the choroid plexus in monkeys $(39,74)$, NNC126-0083 related to unsatisfactory IGFI profiles at the doses administered $(39,74)$, PHA-794428 due to high rates of injection-site lipoatrophy (mainly in women) (47), TV-1106 due to the development of potentially inactivating antibodies (10), and ALTU-238 because the manufacturer had run out of funds $(74,75)$. On the other hand, studies on the efficacy and safety of other LAGH analogs, such as GX-H9, show promise and are currently being evaluated in ongoing Phase 3 clinical trials (76).

In April 2020, TransCon GH (Lonapegsomatropin ${ }^{\circledR}$, Ascendis Pharma A/S), a sustained-release inactive prodrug of unmodified GH transiently bound to an inert carrier molecule designed to release fully active GH over one week, was granted Orphan Drug Designation by the FDA, after previously receiving Orphan Designation for the treatment of GHD in Europe from the European Commission in October 2019 (https://www. globenewswire.com/news-release/2020/04/15/2016859/0/en/ Ascendis-Pharma-A-S-Receives-Orphan-Drug-Designation-forTransCon-hGH-as-Treatment-for-Growth-HormoneDeficiency-in-the-United-States.html). In a Phase 1 randomized trial, 44 healthy subjects were treated with 4 different doses of weekly TransCon GH and 2 different doses of daily rhGH. These investigators discovered that TransCon GH was well-tolerated with no binding antibody formation and comparable levels of serum GH and IGF-I were obtained (12). Phase 2 trials in 37 adults with GHD and 53 previously untreated prepubertal children with GHD also revealed comparable safety and efficacy of TransCon GH when compared to daily rhGH (8, 14). In a recent Phase 3 heiGHt trial (NCT02781727) (18) involving 161 previously untreated prepubertal children with GHD that received either weekly TransCon GH or daily Genotropin, annualized height velocity after 1 year was greater with TransCon GH compared to Genotropin (11.2 vs $10.3 \mathrm{~cm})$. The preliminary data of the Phase 3 fliGHt trial (NCT03305016) on children with GHD who switched over from daily rhGH injections to once-weekly TransCon injections were presented at the 2020 Endocrine Society Annual Meeting (ENDO 2020) (77). In this study, dose titrations of TransCon GH demonstrated a predictable serum IGF-I response and a similar side-effect profile to daily rhGH therapy. Ascendis Pharma A/S reports that an application to the FDA and European Medicines Agency has been filed based on these data and those from fliGHt and
enliGHten (long-term extension) studies with a Prescription Drug User Fee Act date tentatively set for June 25, 2021 (78).

In June 2020, the data from a Phase 3 trial of Somatrogon hGH-CTP (MOD-4023, Pfizer/OPKO Biologics), a long-acting derivative of rhGH modified by the addition of three C-terminal peptide segments from human chorionic gonadotropin to allow for once-weekly delivery, in children with GHD (NCT02968004) were presented at ENDO 2020 (79). Previously untreated prepubertal children with GHD received either weekly Somatrogon hGH-CTP $(0.66 \mathrm{mg} / \mathrm{kg} / \mathrm{wk})$ or once daily Genotropin $(0.24 \mathrm{mg} / \mathrm{kg} / \mathrm{wk})$ for 12 months. The annualized height velocity annualized height velocity after 1 year on Somatrogon hGH-CTP therapy was higher and non-inferior compared to Genotropin (10.1 vs $9.8 \mathrm{~cm}$ ). This trial also demonstrated that children receiving Somatrogon hGH-CTP reported good tolerability with lower treatment burden than Genotropin. Based on these data, Pfizer Inc. is expected to file for FDA approval in early 2021 (80).

In August 2020, once-weekly Somapacitan (Sogroya ${ }^{\circledR}$, Novo Nordisk A/S, Denmark) was approved by the FDA for treatment of adult GHD (https://www.fda.gov/drugs/drug-safety-andavailability/fdaapproves-weekly-therapy-adult-growth-hormonedeficiency). Somapacitan is a long-acting human GH derivative to which a small noncovalent albumin-binding moiety is attached to facilitate reversible binding to endogenous albumin, delaying its elimination, and thereby extending its duration of action with little to no accumulation of the drug when administered once-weekly (52). In previous short-term clinical trials, Somapacitan was welltolerated in healthy adults (81) and in adults and children with $\operatorname{GHD}(53,54,82)$, and provided similar safety and efficacy to daily rhGH in previously rhGH-treated adults with $\operatorname{GHD}(54,55)$. In a Phase 3, 26-week randomized, controlled multi-center study of 92 adults with GHD treated with Somapacitan or daily Norditropin, Somapacitan was well-tolerated, IGF-I standard deviation scores remained in the therapeutic range, and patients preferred the weekly Somapacitan therapy (54). In another Phase 3 study (REAL 1 trial -NCT02229851) of 257 adults with GHD, Somapacitan treatment for 86 weeks demonstrated superiority to placebo in improving body composition and serum IGF-I levels (56), and was well-tolerated with patients preferring Somapacitan to daily rhGH injections for administration convenience. However, although recently approved by the FDA in the United States, Somapacitan will not be available for commercial use in the foreseeable future as the launch date is yet to be determined by its manufacturer. Conversely, the Phase 3 testing of Somapacitan (REAL 4 trial NCT03811535) in children with GHD commenced in 2019 and is expected to conclude sometime in 2021 (83).

\section{POTENTIAL PITFALLS OF LAGH ANALOGS}

Questions have arisen regarding dosing (particularly whether there are any differences in dose initiation between GH-naïve and switch-over patients from rhGH daily injection and how to adjust dosing during therapy), safety monitoring, and whether 
LAGH analogs would be as effective and safe compared to daily rhGH because of the differences in pharmacokinetics and pharmacodynamics, as they are not physiologic. Furthermore, because the therapeutic response to daily rhGH injections can be highly variable among patients and may be influenced by multiple factors (e.g., age, time of diagnosis of GHD, gender, body mass index, severity of GHD, quality of life, other pituitary hormone replacements, and GH receptor polymorphisms) (84), it is likely that similar variability to therapeutic responses will be observed with LAGH analogs as well.

It is also anticipated that LAGH analogs will share many, if not all, of the known side-effects of daily rhGH. However, because of the mechanism by which $\mathrm{GH}$ action is prolonged and the duration of prolongation, additional safety risks may be present. New safety concerns may include the formation of neutralizing anti-drug antibodies, and growth and metabolic effects related to the altered profile of serum GH and IGF-I levels during therapy. Furthermore, in those drugs where modifications of the $\mathrm{GH}$ molecule have been made, there may be a risk of anti-GH antibodies developing. Anti-GH antibodies formed against rhGH given as a daily injection have not been previously shown to be clinically relevant, except in individuals with $\mathrm{GH}$ gene deletions $(85,86)$. If neutralizing antibodies develop against a modified GH molecule, there is a possibility that the individual would not or only partially respond to the unmodified rhGH. As the methods of measuring anti-drug antibodies are not universally consistent, it is important to determine its clinical impact and long-term clinical relevance. Additionally, accurate and reliable anti-drug antibody assays for each LAGH available are required and be made available to clinicians, and when to test for these antibodies while on treatment. Furthermore, it remains unknown if the likelihood of developing anti-drug antibodies is increased if an individual is inevitably switched from one LAGH analog to another.

Another potential pitfall of LAGH analogs is the impact of prolonged elevated serum GH levels after an injection of a LAGH analog resulting in the relative lack of daily GH nocturnal peak and daytime trough profile, unlike the profile with daily rhGH injections at bedtime. This may cause long-term metabolic aberrations since $\mathrm{GH}$ is closely involved in the regulation of fat and glucose metabolism, and body composition $(39,87,88)$. Furthermore, due to the low levels of GH prior to the next LAGH injection, the use of LAGH in infants and young children with hypoglycemia associated with severe GHD may put them at unnecessary risk. To date, clinical trials of LAGH have not included children less than 2.5 years of age. Growth hormone fusion proteins may have differing therapeutic efficacy profiles because access of the modified GH may be restricted to different key target tissues due to the large overall size of the protein.

The profile of the IGF-I response to each LAGH analog that differs from daily rhGH injections may present with some unique safety concerns. Early epidemiological studies have demonstrated associations of elevated and high normal serum IGF-I levels with increased risk of cancers (89). A specific serum IGF-I cut-off level has not been identified above which there is documented increase in the risk of any known side-effect of daily
rhGH injections (1). Depending upon the bioavailability of the LAGH analogs and dose administered, peak serum IGF-I levels achieved with LAGH may need to be relatively higher in order to achieve therapeutic clinical efficacy, but whether there are negative implications of transient elevations of serum IGF-I levels remains to be elucidated. Better understanding of the pharmacokinetic and pharmacodynamic profiles of each individual LAGH analog is required to ascertain the optimal timing of serum IGF-I measurements for both safety and efficacy. Other methodologies of assessing serum IGF-I levels that do not need to take into account of the timing of serum IGF-I measurement in relation to the LAGH analog injections, such as calculating the IGF-I area under the curve, utilizing a mathematical formula and/or measuring other surrogate markers, may be considered but needs further studies to validate their accuracy and reliability. It is also important to avoid inducing supra-physiological IGF-I levels for too long in between LAGH analog injections (39), as this could increase the risk of iatrogenic acromegaly, neoplasia and glucose intolerance. In children with GHD, although monitoring of serum IGF-I levels is recommended, hard evidence supporting this practice or finding a "safe" upper limit to target serum IGF-I levels are lacking (1). Conversely, the question of when to measure serum IGF-I levels does not pose such an issue with daily rhGH injections because these levels stabilize several days after injection, so measurements of that hormone at any time during therapy can been used as a basis to guide dosing. As for LAGH analogs, serum IGF-I levels can rise and fall over several days and may differ in the degree of fluctuations between injections with different LAGH analogs. Therefore, it is still unclear if dosing adjustments of LAGH analogs should be adjusted based on the peak, nadir, or a mathematically calculated mean of several serum IGF-I measurements in between injections, and whether these factors differ between other LAGH analogs.

When new LAGH analogs become commercially available, their use in clinical practice will be determined by coverage through insurance programs or government health policies. In countries with a single payer program, the coverage of LAGH analogs will be assessed not only for safety and efficacy, but also for cost-effectiveness compared with daily rhGH injections. It is possible that insurance carriers and governmental health policies may decide against covering LAGH analogs simply for the sole purpose that LAGH analogs are "convenient" because of the lower frequency of administration, especially if the costs are higher than daily rhGH injections.

Finally, post-marketing surveillance registries are recommended to enable surveillance of LAGH analogs for efficacy, safety, tolerability, cost-effectiveness, and therapeutic durability. Since each individual LAGH analog is unique in its formulation and molecular structure, further studies are needed for each individual LAGH molecule to better understand its pharmacokinetic and pharmacodynamic properties. It would be even more beneficial to set up a combined registry of all LAGH analogs used for treatment of children and adults with GHD in an independent data repository supported by the manufacturers of these compounds. This would enable manufacturers to fulfil their obligatory safety reporting 
requirements from governmental agencies, facilitate collaborative "real-world" studies, and increase the power of the studies. A global registry would also be an ideal platform to capture the data on the impact of patients being initiated or switched from daily rhGH to LAGH analogs and from one LAGH analog to another.

\section{DISCUSSION}

The major usefulness of LAGH analogs when compared with current rhGH formulations is that the former requires significantly lesser number of injections compared to the latter. However, given the unphysiologic profile of LAGH analogs, new safety concerns have been raised. Prolonged elevated GH levels might induce supra-physiologic serum IGF-I levels and induce iatrogenic acromegaly, neoplasia and glucose intolerance. Nevertheless, these concerns have reassuringly not been substantiated by any robust evidence in numerous published clinical trials thus far. Because each individual LAGH analog has its own unique pharmacokinetic and pharmacodynamic features, safety issues, dose titrations and therapeutic monitoring need to be individually addressed. Pitfalls of LAGH analogs include whether there are pathophysiological long-term implications of prolonged supra-physiologic elevations of serum GH and IGF-I levels, differences in tissue distribution and tissue sensitivity to modified GH molecules, development of anti-drug antibodies, and differences in the side-effect profile compared with daily

\section{REFERENCES}

1. Allen DB, Backeljauw P, Bidlingmaier M, Biller BM, Boguszewski M, Burman $\mathrm{P}$, et al. Growth hormone safety workshop position paper: a critical appraisal of recombinant human GH therapy in children and adults. Eur J Endocrinol (2016) 174:P1-9. doi: 10.1530/EJE-15-0873

2. Grimberg A, DiVall SA, Polychronakos C, Allen DB, Cohen LE, Quintos JB, et al. Drug, Therapeutics C, Ethics Committee of the Pediatric Endocrine S. Guidelines for growth hormone and insulin-like growth factor-I treatment in children and adolescents: growth hormone deficiency, idiopathic short stature, and primary insulin-like growth factor-I deficiency. Horm Res Paediatr (2016) 86:361-97. doi: 10.1159/000452150

3. Richmond E, Rogol AD. Treatment of growth hormone deficiency in children, adolescents and at the transitional age. Best Pract Res Clin Endocrinol Metab (2016) 30:749-55. doi: 10.1016/j.beem.2016.11.005

4. Holdaway IM, Hunt P, Manning P, Cutfield W, Gamble G, Ninow N, et al. Three-year experience with access to nationally funded growth hormone (GH) replacement for GH-deficient adults. Clin Endocrinol (Oxf) (2015) 83:85-90. doi: 10.1111/cen.12691

5. Kremidas D, Wisniewski T, Divino VM, Bala K, Olsen M, Germak J, et al. Administration burden associated with recombinant human growth hormone treatment: perspectives of patients and caregivers. J Pediatr Nurs (2013) 28:55-63. doi: 10.1016/j.pedn.2011.12.006

6. Hughes IP, Choong C, Rath S, Atkinson H, Cotterill A, Cutfield W, et al. Early cessation and non-response are important and possibly related problems in growth hormone therapy: An OZGROW analysis. Growth Horm IGF Res (2016) 29:63-70. doi: 10.1016/j.ghir.2016.04.006

7. Battelino T, Rasmussen MH, De Schepper J, Zuckerman-Levin N, Gucev Z, Savendahl L, et al. Somapacitan, a once-weekly reversible albuminbinding GH derivative, in children with $\mathrm{GH}$ deficiency: A randomized dose-escalation trial. Clin Endocrinol (Oxf) (2017) 87:350-8. doi: 10.1111/ cen.13409
rhGH injections. The cost-effectiveness of LAGH analogs vs daily rhGH injections is another key question that requires resolution. Perhaps the key overarching question is will LAGH analogs increase treatment adherence, and improve treatment efficacy and long-term outcomes without sacrificing patient safety? Though it seems plausible that this presumption might hold true in certain patient populations, this question to date has not been proven and needs to be prospectively tested further in welldesigned clinical trials with the answer likely to be dependent on multiple external and individual factors. Clearly there is still much to be learned moving forward in the coming years, but for now, the available data seem to suggest that LAGH analogs are a useful addition to currently available daily rhGH injections, especially for patients who are not coping with the rigors of daily rhGH injections but yet are wanting to continue as they are obtaining clear benefits from this therapy. Finally, we recommend starting surveillance registries once LAGH analogs are approved and become commercially available so that data on efficacy, safety, tolerability, and cost-effectiveness can be collected in large numbers to improve our understanding of the effects of prolonged exposure to these analogs.

\section{AUTHOR CONTRIBUTIONS}

All authors listed have made a substantial, direct, and intellectual contribution to the work and approved it for publication.

8. Chatelain P, Malievskiy O, Radziuk K, Senatorova G, Abdou MO, Vlachopapadopoulou E, et al. A randomized Phase 2 study of long-acting TransCon GH vs daily GH in childhood GH deficiency. J Clin Endocrinol Metab (2017) 102:1673-82. doi: 10.1210/jc.2016-3776

9. Cohen-Barak O, Barkay H, Rasamoelisolo M, Butler K, Yamada K, Bassan M, et al. Assessment of the pharmacokinetics, pharmacodynamics, and safety of single doses of TV-1106, a long-acting growth hormone, in healthy Japanese and Caucasian subjects. Clin Pharmacol Drug Dev (2017) 6:331-42. doi: $10.1002 /$ cpdd. 294

10. Cohen-Barak O, Sakov A, Rasamoelisolo M, Bassan M, Brown K, Mendzelevski B, et al. Safety, pharmacokinetic and pharmacodynamic properties of TV-1106, a long-acting GH treatment for GH deficiency. Eur J Endocrinol (2015) 173:541-51. doi: 10.1530/EJE-15-0554

11. Fisher DM, Rosenfeld RG, Jaron-Mendelson M, Amitzi L, Koren R, Hart G. Pharmacokinetic and pharmacodynamic modeling of MOD-4023, a longacting human growth hormone, in growth hormone deficiency children. Horm Res Paediatr (2017) 87:324-32. doi: 10.1159/000470842

12. Gilfoyle D, Mortensen E, Christoffersen ED, Leff JA, Beckert M. A first-inman phase 1 trial for long-acting TransCon Growth Hormone. Growth Horm IGF Res (2018) 39:34-9. doi: 10.1016/j.ghir.2017.12.002

13. Hou L, Chen ZH, Liu D, Cheng YG, Luo XP. Comparative pharmacokinetics and pharmacodynamics of a PEGylated recombinant human growth hormone and daily recombinant human growth hormone in growth hormone-deficient children. Drug Des Devel Ther (2016) 10:13-21. doi: 10.2147/DDDT.S93183

14. Hoybye C, Pfeiffer AF, Ferone D, Christiansen JS, Gilfoyle D, Christoffersen ED, et al. A phase 2 trial of long-acting TransCon growth hormone in adult GH deficiency. Endocr Connect (2017) 6:129-38. doi: 10.1530/EC-17-0007

15. Kramer WG, Jaron-Mendelson M, Koren R, Hershkovitz O, Hart G. Pharmacokinetics, pharmacodynamics, and safety of a long-acting human growth hormone (MOD-4023) in healthy Japanese and Caucasian adults. Clin Pharmacol Drug Dev (2017) 7(5):554-63. doi: 10.1002/cpdd.414 
16. Luo X, Hou L, Liang L, Dong G, Shen S, Zhao Z, et al. Long-acting PEGylated recombinant human growth hormone (Jintrolong) for children with growth hormone deficiency: phase II and phase III multicenter, randomized studies. Eur J Endocrinol (2017) 177:195-205. doi: 10.1530/EJE-16-0905

17. Strasburger CJ, Vanuga P, Payer J, Pfeifer M, Popovic V, Bajnok L, et al. MOD-4023, a long-acting carboxy-terminal peptide-modified human growth hormone: results of a Phase 2 study in growth hormone-deficient adults. Eur J Endocrinol (2017) 176:283-94. doi: 10.1530/EJE-16-0748

18. Thornton P, Hofman P, Maniatis A, Aghajanova E, Chertok E, KorpalSzczyrska M, et al. TransCon growth hormone in the treatment of pediatric growth hormone deficiency: results of the Phase 3 heiGHt trial. J Endocrinol Soc (2019) 3:OR17-14. doi: 10.1210/js.2019-OR17-4

19. Hoffman AR, Biller BM, Cook D, Baptista J, Silverman BL, Dao L, et al. Genentech Adult Growth Hormone Deficiency Study G. Efficacy of a longacting growth hormone $(\mathrm{GH})$ preparation in patients with adult $\mathrm{GH}$ deficiency. J Clin Endocrinol Metab (2005) 90:6431-40. doi: 10.1210/ jc.2005-0928

20. Kemp SF, Fielder PJ, Attie KM, Blethen SL, Reiter EO, Ford KM, et al. Pharmacokinetic and pharmacodynamic characteristics of a long-acting growth hormone $(\mathrm{GH})$ preparation (nutropin depot) in GH-deficient children. J Clin Endocrinol Metab (2004) 89:3234-40. doi: 10.1210/jc.2003030825

21. Silverman BL, Blethen SL, Reiter EO, Attie KM, Neuwirth RB, Ford KM. A long-acting human growth hormone (Nutropin Depot): efficacy and safety following two years of treatment in children with growth hormone deficiency. J Pediatr Endocrinol Metab 2002 (15) Suppl2:715-22. doi: 10.1515/ JPEM.2002.15.S2.715

22. Moore WV, Nguyen HJ, Kletter GB, Miller BS, Rogers D, Ng D, et al. A randomized safety and efficacy study of somavaratan (VRS-317), a long-acting rhGH, in pediatric growth hormone deficiency. J Clin Endocrinol Metab (2016) 101:1091-7. doi: 10.1210/jc.2015-3279

23. Yuen KC, Conway GS, Popovic V, Merriam GR, Bailey T, Hamrahian AH, et al. A long-acting human growth hormone with delayed clearance (VRS317): results of a double-blind, placebo-controlled, single ascending dose study in growth hormone-deficient adults. J Clin Endocrinol Metab (2013) 98:2595-603. doi: 10.1210/jc.2013-1437

24. Laursen T, Gravholt CH, Heickendorff L, Drustrup J, Kappelgaard AM, Jorgensen JO, et al. Long-term effects of continuous subcutaneous infusion versus daily subcutaneous injections of growth hormone (GH) on the insulinlike growth factor system, insulin sensitivity, body composition, and bone and lipoprotein metabolism in GH-deficient adults. J Clin Endocrinol Metab (2001) 86:1222-8. doi: 10.1210/jc.86.3.1222

25. Burns EC, Tanner JM, Preece MA, Cameron N. Final height and pubertal development in 55 children with idiopathic growth hormone deficiency, treated for between 2 and 15 years with human growth hormone. Eur J Pediatr (1981) 137:155-64. doi: 10.1007/BF00441309

26. Kastrup KW, Christiansen JS, Andersen JK, Orskov H. Increased growth rate following transfer to daily sc administration from three weekly im injections of hGH in growth hormone deficient children. Acta Endocrinol (Copenh) (1983) 104:148-52. doi: 10.1530/acta.0.1040148

27. Collett-Solberg PF, Ambler G, Backeljauw PF, Bidlingmaier M, Biller BMK, Boguszewski MCS, et al. Diagnosis, genetics, and therapy of short stature in children: a Growth Hormone Research Society international perspective. Horm Res Paediatr (2019) 92:1-14. doi: 10.1159/000502231

28. Jorgensen JO, Pedersen SA, Thuesen L, Jorgensen J, Ingemann-Hansen T, Skakkebaek NE, et al. Beneficial effects of growth hormone treatment in GHdeficient adults. Lancet (1989) 1:1221-5. doi: 10.1016/S0140-6736(89)92328-3

29. Salomon F, Cuneo RC, Hesp R, Sonksen PH. The effects of treatment with recombinant human growth hormone on body composition and metabolism in adults with growth hormone deficiency. N Engl J Med (1989) 321:1797-803. doi: 10.1056/NEJM198912283212605

30. de Boer H, Blok GJ, Popp-Snijders C, Stuurman L, Baxter RC, van der Veen E. Monitoring of growth hormone replacement therapy in adults, based on measurement of serum markers. J Clin Endocrinol Metab (1996) 81:1371-7. doi: $10.1210 /$ jcem.81.4.8636336

31. Johannsson G, Rosen T, Bengtsson BA. Individualized dose titration of growth hormone $(\mathrm{GH})$ during $\mathrm{GH}$ replacement in hypopituitary adults. Clin Endocrinol (Oxf) (1997) 47:571-81. doi: 10.1046/j.1365-2265.1997.3271123.x
32. Moller J, Jorgensen JO, Lauersen T, Frystyk J, Naeraa RW, Orskov H, et al. Growth hormone dose regimens in adult GH deficiency: effects on biochemical growth markers and metabolic parameters. Clin Endocrinol (Oxf) (1993) 39:403-8. doi: 10.1111/j.1365-2265.1993.tb02386.x

33. Cuneo RC, Judd S, Wallace JD, Perry-Keene D, Burger H, Lim-Tio S, et al. The Australian multicenter trial of growth hormone $(\mathrm{GH})$ treatment in $\mathrm{GH}$ deficient adults. J Clin Endocrinol Metab (1998) 83:107-16. doi: 10.1210/ jc.83.1.107

34. Burman P, Johansson AG, Siegbahn A, Vessby B, Karlsson FA. Growth hormone $(\mathrm{GH})$-deficient men are more responsive to $\mathrm{GH}$ replacement therapy than women. J Clin Endocrinol Metab (1997) 82:550-5. doi: $10.1210 /$ jc. 82.2 .550

35. Johannsson G, Bjarnason R, Bramnert M, Carlsson LM, Degerblad M, Manhem P, et al. The individual responsiveness to growth hormone (GH) treatment in GH-deficient adults is dependent on the level of GH-binding protein, body mass index, age, and gender. J Clin Endocrinol Metab (1996) 81:1575-81. doi: 10.1210/jcem.81.4.8636370

36. Ho KKGrowth Hormone Deficiency Consensus Workshop Participants. Consensus guidelines for the diagnosis and treatment of adults with GH deficiency II: a statement of the GH Research Society in association with the European Society for Pediatric Endocrinology, Lawson Wilkins Society, European Society of Endocrinology, Japan Endocrine Society, and Endocrine Society of Australia. Eur J Endocrinol (2007) 157:695-700. doi: 10.1530/EJE-07-0631

37. Molitch ME, Clemmons DR, Malozowski S, Merriam GR, Vance ML, Endocrine S. Evaluation and treatment of adult growth hormone deficiency: an Endocrine Society clinical practice guideline. J Clin Endocrinol Metab (2011) 96:1587-609. doi: 10.1210/jc.2011-0179

38. Yuen KCJ, Biller BMK, Radovick S, Carmichael JD, Jasim S, Pantalone KM, et al. American Association of Clinical Endocrinologists and American College of Endocrinology guidelines for management of growth hormone deficiency in adults and patients transitioning from pediatric to adult care. Endocr Pract (2019) 25:1191-232. doi: 10.4158/GL-2019-0405

39. Christiansen JS, Backeljauw PF, Bidlingmaier M, Biller BM, Boguszewski MC, Casanueva FF, et al. Growth Hormone Research Society perspective on the development of long-acting growth hormone preparations. Eur J Endocrinol (2016) 174:C1-8. doi: 10.1530/EJE-16-0111

40. Johnson OL, Cleland JL, Lee HJ, Charnis M, Duenas E, Jaworowicz W, et al. A month-long effect from a single injection of microencapsulated human growth hormone. Nat Med (1996) 2:795-9. doi: 10.1038/nm0796-795

41. Peter F, Bidlingmaier M, Savoy C, Ji HJ, Saenger PH. Three-year efficacy and safety of LB03002, a once-weekly sustained-release growth hormone (GH) preparation, in prepubertal children with GH deficiency (GHD). J Clin Endocrinol Metab (2012) 97:400-7. doi: 10.1210/jc.2011-2234

42. Rhie YJ, Yoo JH, Choi JH, Chae HW, Kim JH, Chung S, et al. Long-term safety and effectiveness of growth hormone therapy in Korean children with growth disorders: 5-year results of LG Growth Study. PloS One (2019) 14:e216927. doi: 10.1371/journal.pone.0216927

43. Hwang JS, Lee HS, Lee KH, Yoo HW, Lee DY, Suh BK, et al. Once-weekly administration of sustained-release growth hormone in Korean prepubertal children with idiopathic short stature: a randomized, controlled Phase II study. Horm Res Paediatr (2018) 90:54-63. doi: 10.1159/000489262

44. European Medicines Agency. CHMP Safety Working Party"s Response to the PDCO Regarding the Use of PEGylated Drug Products in the Paediatric Population. Available at: https://www.ema.europa.eu/en/documents/ scientific-guideline/chmp-safety-working-partys-response-pdco-regardinguse-pegylated-drug-products-paediatric-population_en.pdf (Accessed April $8,2019)$.

45. Cox G. Long-acting Growth Hormone for Treating HIV-Associated Adipose Redistribution Syn. (2008). Available at: https://www.sbir.gov/sbirsearch/ detail/112649 (Accessed April 8, 2019).

46. de Schepper J, Rasmussen MH, Gucev Z, Eliakim A, Battelino T. Long-acting pegylated human GH in children with GH deficiency: a single-dose, doseescalation trial investigating safety, tolerability, pharmacokinetics and pharmacodynamics. Eur (2011) 165:401-9. doi: 10.1530/EJE-11-0536

47. Touraine P, D'Souza GA, Kourides I, Abs R, Barclay P, Xie R, et al. Lipoatrophy in $\mathrm{GH}$ deficient patients treated with a long-acting pegylated GH. Eur J Endocrinol (2009) 161:533-40. doi: 10.1530/EJE-09-0422 
48. Sprogoe K, Mortensen E, Karpf DB, Leff JA. The rationale and design of TransCon Growth Hormone for the treatment of growth hormone deficiency. Endocr Connect (2017) 6:R171-81. doi: 10.1530/EC-17-0203

49. Beckert M, Brian Karpf D, Mortensen E, Mardell J, Christoffersen ED, Leff JA. Design and rationale for the height trial, a phase 3 transcon GH study in children with growth hormone deficiency, in: Endocrine Reviews. Conference: 99th Annual Meeting of the Endocrine Society, ENDO 2017. United States. Vol 38. Orlando, FL (2017). Available at: https://www.cochranelibrary.com/ central/doi/10.1002/central/CN-01399931/full (Accessed April 8, 2019).

50. Thygesen P, Andersen HS, Behrens C, Fels JJ, Norskov-Lauritsen L, Rischel C, et al. Nonclinical pharmacokinetic and pharmacodynamic characterisation of somapacitan: A reversible non-covalent albumin-binding growth hormone. Growth Horm IGF Res (2017) 35:8-16. doi: 10.1016/j.ghir.2017.05.006

51. Thygesen P, Konradsen G, Schjødt CB, Nielsen PF. (NNC0195-0092) a Novel Long Acting Human GH Derivative Binds Tightly, but Reversibly to Albumin in Plasma. In: The Endocrine Society's 98th Annual Meeting and Expo, April 1-4, 2016. San Diego, CA: Endocr Rev (2016). 37(Issue Supplement, 1 April 2016):i1-i1699. doi: 10.1093/edrv/37.supp.1

52. Juul RV, Rasmussen MH, Agerso H, Overgaard RV. Pharmacokinetics and pharmacodynamics of once-weekly Somapacitan in children and adults: supporting dosing rationales with a model-based analysis oft Three phase I trials. Clin Pharmacokinet (2019) 58:63-75. doi: 10.1007/s40262-018-0662-5

53. Savendahl L, Battelino T, Brod M, Hojby Rasmussen M, Horikawa R, Juul RV, et al. Once-weekly somapacitan vs daily GH in children with GH deficiency: results from a randomized phase 2 trial. J Clin Endocrinol Metab (2020) 105: e1847-61. doi: 10.1210/clinem/dgaa614

54. Johannsson G, Feldt-Rasmussen U, Hakonsson IH, Biering H, Rodien P, Tahara S, et al. Safety and convenience of once-weekly somapacitan in adult GH deficiency: a 26-week randomized, controlled trial. Eur J Endocrinol (2018) 178:491-9. doi: 10.1530/EJE-17-1073

55. Otsuka F, Takahashi Y, Tahara S, Ogawa Y, Hojby Rasmussen M, Takano K. Similar safety and efficacy in previously treated adults with growth hormone deficiency randomized to once-weekly somapacitan or daily growth hormone. Clin Endocrinol (Oxf) (2020) 93:620-8. doi: 10.1111/cen.14273

56. Johannsson G, Gordon MB, Hojby Rasmussen M, Hakonsson IH, Karges W, Svaerke C, et al. Once-weekly Somapacitan is effective and well tolerated in adults with GH deficiency: a randomized phase 3 trial. J Clin Endocrinol Metab (2020) 105(4):e1358-76. doi: 10.1210/clinem/dgaa049

57. Kim Y, Jang JS, Hur B, Shin H, Kang H, Chang K-h, et al. Preclinical Pharmacokinetic and Pharmacodynamic Studies of a Novel, Long Acting Growth Hormone (AG-B1512). In: The Endocrine Society's 99th Annual Meeting and Expo, April 1-4, 2017. Orlando, FL: Endocr Rev (2017). 38 (Issue Supplement, 1 June 2017):i1-i1431. doi: 10.1093/edrv/38.supp.1

58. Lee SM, Cho J-S, Chung H-S, Park MS, Park SJ. Human Phase 1 Clinical Data of ALT-P1 (hGH-NexP) by Healthy Korean Males. Horm Res Paediatr (2016) 86(suppl 1):1-598. doi: 10.1159/000449142

59. Alteogen Inc - ALT-P1. Available at: http://alteogen.cafe24.com/en/alt-p1/ (Accessed April 8, 2019).

60. Wilkinson IR, Ferrandis E, Artymiuk PJ, Teillot M, Soulard C, Touvay C, et al. Ross RJ. A ligand-receptor fusion of growth hormone forms a dimer and is a potent long-acting agonist. Nat Med (2007) 13:1108-13. doi: 10.1038/ nm1610

61. Kim ES, Jang DS, Yang SY, Lee MN, Jin KS, Cha HJ, et al. Controlled release of human growth hormone fused with a human hybrid $\mathrm{Fc}_{\mathrm{c}}$ fragment through a nanoporous polymer membrane. Nanoscale (2013) 5:4262-9. doi: 10.1039/ c3nr00474k

62. Lee H, Kim T, Lee J, Heo M-K, Kim Y-J, Koh H, et al. A PharmacokineticPharmacodynamic Analysis Of GX-H9, A Long-acting Hybrid Fc-fused Recombinant Human Growth Hormone (rhGH). In: The Endocrine Society's 100th Annual Meeting and Expo, March 17-20, 2018. Chicago, IL: Endocr Rev (2018). 39(Issue Supplement, 1 April 2018):i1-i1417. doi: 10.1093/edrv/39.supp.1

63. Ku CR, Brue T, Schilbach K, Ignatenko S, Magony S, Chung YS, et al. Longacting FC-fusion rhGH (GX-H9) shows potential for up to twice-monthly administration in GH-deficient adults. Eur J Endocrinol (2018) 179:169-79. doi: 10.1530/EJE-18-0185

64. Kang J, Kim P, Kwak EH, Xu M-Y, Han O, Kim Y, et al. A Novel Long Acting Growth Hormone (HM10560A) Demonstrated Good Tolerability and
Weekly Potential in Healthy Male Subjects after Single Administration. In: The Endocrine Society's 97th Annual Meeting and Expo, March 5-8, 2015. San Diego, CA:Endocr Rev (2015). 36(Issue Supplement, 1 April 2015):i1-i1599. doi: 10.1093/edrv/36.supp.1

65. Kang J, Kim P, Kwak EH, Xu M-Y, Han O, Kim Y, et al. 6 Month Results of a Phase II, Randomized, Active Controlled, Open Label Study of Safety and Efficacy of HM10560A a Long Acting r-Hgh-HMC001 Conjugate in Adult Patients with Growth Hormone Deficiency (AGHD). In: The Endocrine Society's 97th Annual Meeting and Expo, March 5-8, 2015. San Diego, CA: Endocr Rev (2015). 36(Issue Supplement, 1 April 2015):i1-i1599. doi: 10.1093/edrv/36.supp.1

66. JCR Pharmaceuticals Co. JCR Pharmaceuticals Development Pipeline. Available at: http://www.jcrpharm.co.jp/en/site/en/biopharmaceutical/pdf/ pipeline_190621.pdf (Accessed November 20, 2020).

67. JCR Announces Completion of Phase 1 Clinical Trial Notification of JR-142, A long-acting growth hormone. Available at: http://www.jcrpharm.co.jp/ en/site/en/ir/en_news/jcr-announces-completion-of-phase-1-clinical-trialnotification-of-jr-142-a-long-acting-growth-hormone (Accessed November 20, 2020).

68. Zelinska N, Iotova V, Skorodok J, Malievsky O, Peterkova V, Samsonova L, et al. Long-Acting C-Terminal Peptide-Modified hGH (MOD-4023): Results of a Safety and Dose-Finding Study in GHD Children. J Clin Endocrinol Metab (2017) 102:1578-87. doi: 10.1210/jc.2016-3547

69. ClinicalTrials.gov. Safety and Efficacy Study of MOD-4023 to Treat Children With Growth Hormone Deficiency. Available at: https://clinicaltrials.gov/ct2/ show/NCT03874013?term $=$ mod-4023\&rank=1 (Accessed November 26, 2020).

70. Miller BS, Velazquez E, Yuen KCJ. Long-acting growth hormone preparations - current status and future considerations. J Clin Endocrinol Metab (2020) 105(6):dgz149. doi: 10.1210/clinem/dgz149

71. Lippe B, Frasier SD, Kaplan SA. Use of growth hormone-gel. Arch Dis Child (1979) 54:609-13. doi: 10.1136/adc.54.8.609

72. Biller BM, Ji HJ, Ahn H, Savoy C, Siepl EC, Popovic V, et al. Twelve-month effects of once-weekly sustained-release growth hormone treatment in adults with GH deficiency. Pituitary (2013) 16:311-8. doi: 10.1007/s11102-012$0422-8$

73. Versartis Inc. Available at: http://ir.versartis.com/news-releases/news-releasedetails/versartis-reports-fourth-quarter-and-full-year-2017-financial (Accessed November 20, 2020).

74. Hoybye C, Cohen P, Hoffman AR, Ross R, Biller BM, Christiansen JS, et al. Status of long-acting-growth hormone preparations-2015. Growth Horm IGF Res (2015) 25:201-6. doi: 10.1016/j.ghir.2015.07.004

75. McBride R. Available at: https://www.xconomy.com/boston/2009/09/15/ altus-pharma-to-shut-doors/ (Accessed November 20, 2020).

76. Boguszewski CL. Update on GH therapy in adults. F1000Res (2017) 6:2017. doi: 10.12688/f1000research.12057.1

77. Maniatis AK, Nadgir U, Saenger P, Mick G, Reifschneider KL, Abuzzahab MJ, et al. Phase 3 fliGHt trial: experience of switching from daily growth hormone therapy to once-weekly TransCon HGH in children with growth hormone deficiency. J Endocrinol Soc (2020) 4(Suppl 1):OR10-05. doi: 10.1210/jendso/ bvaa046.963

78. Ascendis Pharma. Available at: https://www.globenewswire.com/newsrelease/2020/04/15/2016859/0/en/Ascendis-Pharma-A-S-Receives-OrphanDrug-Designation-for-TransCon-hGH-as-Treatment-for-Growth-HormoneDeficiency-in-the-United-States.html (Accessed November 28, 2020).

79. Deal C, Pastrak A, Silverman LA, Valluri SR, Wajnrajch MP, Cara JF. Somatrogon growth hormone in the treatment of pediatric growth hormone deficiency: results of the pivotal pediatric Phase 3 clinical trial. J Endocrinol Soc (2020) 4(Suppl 1):A648-9. doi: 10.1210/jendso/bvaa046.1279

80. Biospace. Available at: https://www.biospace.com/article/pfizer-s-treatmentfor-growth-hormone-deficiency-hits-mark-in-phase-iii-trial/ (Accessed November 28, 2020).

81. Rasmussen MH, Olsen MW, Alifrangis L, Klim S, Suntum M. A reversible albumin-binding growth hormone derivative is well tolerated and possesses a potential once-weekly treatment profile. J Clin Endocrinol Metab (2014) 99: E1819-1829. doi: 10.1210/jc.2014-1702

82. Rasmussen MH, Janukonyte J, Klose M, Marina D, Tanvig M, Nielsen LF, et al. Reversible albumin-binding GH possesses a potential once-weekly 
treatment profile in adult growth hormone deficiency. J Clin Endocrinol Metab (2016) 101:988-98. doi: 10.1210/jc.2015-1991

83. ClinicalTrials.gov. Available at: https://www.clinicaltrials.gov/ct2/results? cond $=\&$ term $=$ NCT $03811535 \& c n t r y=\&$ state $=\& c i t y=\&$ dist $\quad($ Accessed November 20, 2020).

84. Boguszewski CL. Individual sensitivity to growth hormone replacement in adults. Rev Endocr Metab Disord (2020). doi: 10.1007/s11154-020-09605-1

85. Ahangari G, Ostadali MR, Rabani A, Rashidian J, Sanati MH, Zarindast MR. Growth hormone antibodies formation in patients treated with recombinant human growth hormone. Int J Immunopathol Pharmacol (2004) 17:33-8. doi: $10.1177 / 039463200401700105$

86. Binder G, Heidenreich L, Schnabel D, Dunstheimer D, Oeverink R, Kiess W, et al. Biological Significance of Anti-GH Antibodies in Children Treated with rhGH. Horm Res Paediatr (2019) 91:17-24. doi: 10.1159/000497409

87. Hoybye C, Christiansen JS. Long-acting growth hormone. Paediatr Drugs (2013) 15:427-9. doi: 10.1007/s40272-013-0059-8

88. Johannsson G. Long-acting growth hormone for replacement therapy. J Clin Endocrinol Metab (2011) 96:1668-70. doi: 10.1210/jc.2011-0689

89. Pollak M. Insulin and insulin-like growth factor signalling in neoplasia. Nat Rev Cancer (2008) 8:915-28. doi: 10.1038/nrc2536
Conflict of Interest: KY is an investigator on research grants from Pfizer, Novo Nordisk, and OPKO Biologics, and has consulted for Pfizer, Novo Nordisk, Sandoz, and Ascendis. BM is an investigator on research grants from Alexion, Abbvie, Amgen, Ascendis, Novo Nordisk, OOKO Biologics, Protalix, Sangamo, Sanofi Genzyme, Tolmar, and Takeda and has consulted for Abbvie, Ascendis, BioMarin, Bluebird Bio, Novo Nordisk, Pfizer, Sandoz, Sanofi Genzyme, Tolmar, and Vertice. $\mathrm{AH}$ is supported by the Biomedical Research Service of the Department of Veterans Affairs and has consulted for Ascendis, GeneScience, Genexine, Novo Nordisk, Pfizer, and Versartis.

The remaining author declares that the research was conducted in the absence of any commercial or financial relationships that could be construed as a potential conflict of interest.

Copyright $\odot 2021$ Yuen, Miller, Boguszewski and Hoffman. This is an open-access article distributed under the terms of the Creative Commons Attribution License (CC BY). The use, distribution or reproduction in other forums is permitted, provided the original author(s) and the copyright owner(s) are credited and that the original publication in this journal is cited, in accordance with accepted academic practice. No use, distribution or reproduction is permitted which does not comply with these terms. 